\title{
O refleksji egzystencjalnej w autobiografii staropolskiej
}

Halina Popławska 


\title{
Halina Popławska
}

\section{O refleksji egzystencjalnej w autobiografii staropolskiej}

1.

\begin{abstract}
utobiografia w epoce staropolskiej była ściśle związana z rzeczywistością pozaartystyczA ną, z kulturą społeczeństwa, wyrastała z życia rodziny, rodu, wspólnoty wyznaniowej; posługiwano się nią, gdy chodziło o ważną z punktu widzenia autora sprawę osobistą lub społeczną. Nadawano jej niekiedy formę listu: otwartego, prywatnego. Występowała także jako świadomie użyta forma samopoznania i wprowadzenia członków wspólnoty zakonnej w doświadczenia religijne jednostki wybitnej, osoby, która przeszła „oczyszczenie” i stała się duchowo doskonała.
\end{abstract}

Godny uwagi jest fakt, iż pierwsze polskie autobiografie to utwory literatów, artystów. Pisarze jako pierwsi podjęli temat własnego życia; w ich dziełach pojawiają siç próby dzielenia się obserwacjami psychologicznymi, próby portretowania życia duchowego człowieka, pragnienie dotarcia do sensu i istoty jego egzystencji.

Poetyka omawianego gatunku i jego indywidualnych realizacji tkwi swymi korzeniami w zjawiskach poznawczej i ideowej funkcji utworu. Istotne wydaje się to, z czego dany utwór wyrasta jako obraz świadomości własnego, ludzkiego losu i jaką rolę ma pełnić w stosunku do jego twórcy-nadawcy, a także w odniesieniu do jego czytelnika-odbiorcy. Przedstawione przez autobiografów dzieje życia mają (w zamierzeniu autorskim) nie tylko walor identyfikacyjny, są również próbą uogólnienia losu, kondycji człowieka. Ze swojego życia starają się autorzy wyciągnąć wnioski, zasady i reguły co do postępowania szerszego ogółu czy człowieka w ogóle.

Autobiografie staropolskie w nierównym stopniu nasycone są refleksją nad życiem ludzkim. 
Wyraz „życie”, „żywot” wielokrotnie pojawia się w tytułach i tekstach utworów, występuje w różnych połączeniach i kontekstach, kryjąc w sobie znaczne bogactwo treści.

Życie w rozumieniu wielu autorów jest nauką, służbą publiczną. Pojęcie nauki najczęściej wiążą twórcy autobiografii z poznawaniem i doskonaleniem rzemiosła wojennego, a służbę publiczną z udziałem w wyprawach wojennych, podróżach dyplomatycznych, sejmach. Surowe, wymagające wielu wyrzeczeń i pokonywania trudności życie w służbie ojczyzny jest dla wielu autorów najwłaściwszą, najgodniejszą człowieka egzystencją:

Jest to powinna rzecz każdemu poczuwać się w prawie i wolności, ubliżenia wszelkiego Ojczyzny przestrzegać ${ }^{1}$.

Tragiczne losy bohaterów służących Marsowi i cierpienia ich rodzin ukazała Anna Stanisławska w autobiografii poetyckiej: Transakcyja albo Opisanie catego życia jednej sieroty... Poetka wyraźnie uświadamia sobie, iż „dla wojska i ojca, i męża straciła”.

„Żyć” w przekonaniu autorki Transakcyi znaczy doświadczać rozmaitych uczuć. Zasadniczym tematem utworu Stanisławskiej są dzieje jej uczuć i związków z innymi ludźmi; związków ujętych w dwóch relacjach: konfliktu i sympatii. Tym, co łączy wszystkich ludzi, są w przekonaniu autorki uczucia: rodzicielskie, braterskie, małżeńskie. Stanisławska podkreśla wspólnotę przeżyć i doświadczeń ludzkich, wyrażającą się w powszechnym doznawaniu uczuć przyjaźni i miłości, żalu i cierpienia:

Przecież żal w każdym jest domu, nie chce folgować nikomu².

Odmienny stosunek do życia prezentuje Marianna Marchocka, siedemnastowieczna karmelitanka bosa, twórczyni autobiografii mistycznej, pierwszej polskiej autobiografii napisanej przez kobietę ${ }^{3}$. Życie na ziemi to dla niej „wygnanie”, „piekło”, dlatego nie dba o nie i nie prosi o jego przedłużenie. Ciężary i trudy życia, a przede wszystkim obawa popełnienia grzechu powodują u niej pragnienie śmierci:

Przyszło mi raz po komuniej św. pojęcie trudności tego żywota, iż jeszcze jest człowiek w tym niebezpieczeństwie, że może zgrzeszyć, kiedy by go nie trzymała sama łaska Pańska i nie bronieła. O Panie mój, jakie to ciężkie życie, a $\mathrm{z}$ tej miary nieszczęśliwe! Prosiłam z tego Pana, prawie z zapomnieniem

\footnotetext{
' K. Pieniążek, Ethica albo Zwierciadto żyuota Krzysztofa Pieniqż̇ka rotmistrza i du'orzanina królów Stefana i Zygmunta Trzeciego na Lassochowie i gdzie indziej dziedzica etc. ku przyktadoui braciej okazana, wyd. K. W. Wójcicki, Biblioteka Starożytna Pisarzy Polskich, t. 1, Warszawa 1854, s. 181. Autobiografia Pieniązka cytowana dalej z zastosowaniem skrótu $\mathrm{E}$ i podaniem strony przywołanego fragmentu.

2 A. Stanisławska, Transakcyja albo Opisanie catego życia jednej sieroty przez żałosne treny od tejże samej pisane roku 1685, wyd. I. Kotowa, Kraków 1935, Tren 52, strofa 463. Autorka podzieliła swój tekst na 77 trenów, wydawca opatrzył numeracją kolejne strofy przekazu.

${ }^{3} \mathrm{O}$ żywotach własnych siedemnastowiecznych karmelitanek bosych szerzej w: H. Poplawska, Autobiografia mistyczna, [w:] Religijnośc literatury polskiego baroku, red. Cz. Hernas, M. Hanusiewicz, Lublin 1995, s. 101-123.
} 
sama o sobie, ze wszystkim usiłowaniem o śmierć, nalcgając prośbą Panu, aby mię wziął z tego niebezpieczeństwa (żebym Go już więcy nie obrażała), przez śmicré ${ }^{4}$.

Żywoty własne siedemnastowiecznych karmelitanek: m. Teresy od Jezusa (Marianny Marchockiej), m. Anny od Jezusa (Jadwigi Stobieńskiej), m. Barbary od Najśw. Sakramentu (Teofili z Kretkowskich Zadzikowej) stanowią, w przeciwicństwic do autobiografii polityków, żołnierzy, przedstawicieli zasłużonych dla historii i kultury narodowej rodów, wyraz przemian życia wewnętrznego. „Życie” w najistotniejszej swej części sprowadza się w autobiografiach mistycznych do świata stanów psychicznych. Przedstawione w nich „zdarzenia” mają miejsce przede wszystkim w życiu wewnętrznym: uczuciowym, intelektualnym, religijnym. Autorki zmierzają do wiernego oddania własnych przeżyć duchowych, ujawniają swoje skłonności, konflikty wewnętrzne i międzyludzkie, przedstawiają sposoby zwalczania i pokonywania wątpliwości, pokus.

Rozważając postawy ludzi wobec życia, Krzysztof Pieniążek w Ethica albo Zwierciadto żyota wskazał na właściwą człowiekowi myślącemu jawność jego życia, gotowość do „okazywania spraw swoich”. Autor podkreśla przeznaczenic człowieka do prawdziwie ludzkiego zachowania, do otwartości i ruchliwości, samodzielnej refleksji umysłowej, kształtowania swego życia i świata w sposób zgodny z kondycją i godnością ludzką:

Każdy człowiek albo próżnuje, albo co czyni, a w obojgu tym człowickiem rozumnym być nie przestawa, tego słuszna, aby niczego nie działał, co by go bestyją pokazać mogło, słuszna, aby obojga rejestry prawdziwe miał, których iż sam najlepiej świadom, przystojna zatem i żeby i sąsiedzi o nich wiedzieli. $(\mathrm{E}, 145)$

„Rozumność” człowieka, konieczność przestrzegania prawa i obyczaju podkreśla wielu autorów traktujących swe życie jako zadanie, służbę.

Wydaje się, iż autorzy mają świadomość, że życie ich jest rozwojem, dążeniem do ideału, do osiągnięcia pełni człowieczeństwa. Zespół cech składających się na jednostkę godną miana człowicka „całkowitego”, pełnowartościowego najlepiej oddaje pojęcie humanitas.

Zakres pojęcia rzymskiej humanitatis w języku polskim nic odda w pełni wyraz „ludzkość” ani „człowieczeństwo”, ani „społeczność ludzka”; mieści się w tym pojęciu i godność osobista, i poczucie sprawiedliwości, i wykształcenie; łagodność i tolerancja; umiar i opanowanie; poczucie taktu, szczerość, życzliwość; pogoda wewnętrzna i kultura bycia. Cech tych nabywa człowiek w toku wychowania i samowychowania, w procesie, który można nazwać budowa-

\footnotetext{
' Żuot Wielebnej Matki Teresy a Jesu Klasztoróu we Lwowie i w' Warszawie karmelitanek bosych fundatorki..., [w:] Pisarze ascetyczno-mistyczni Polski, wyd. K. Górski, t. 2: Antobiografia mistyczna M. Teresy od Jezusa karm. bosej (Anny Marii Marchockiej 1603-1652), Poznań 1939, s. 214-215. Źyu'ot cytowany dalej z zastosowaniem skrótu Z i podaniem strony przywołanego fragmentu.
} 
niem człowieka w sobie. Człowieczeństwo jest godnością, którą się zdobywa. Humanitas określa stosunek człowieka do człowieka, do ludzi jako zbiorowości, do państwa ${ }^{5}$.

Zasadom humanitatis starają się dochować wierności twórcy staropolskich autobiografii. Z humanitas związany jest rozsądek, trzeźwe spojrzenie, znajomość własnej natury, które pozwalają człowiekowi popatrzeć krytycznie na samego siebie, ocenić sytuację, okoliczności i wyprowadzić logiczne wnioski, decydować o drodze i sposobie życia. Szczerość każe przyznać się autorom do wad i słabości.

Autobiografie staropolskie nie zawsze pozwalają odkryć wewnętrzną zasadę porządkującą życie autora, nie zawsze w pełni możemy odpowiedzicć na pytanie, czy autor wie, kim jest, czy uzyskał świadomość swojej osobowości, swojego losu. Wnioskować musimy niekiedy ze skąpych refleksji i dygresji autorskich.

Potrzebę zasady, którą należy kierować się w życiu, w nieudolny i nieco zabawny sposób wyraził K. Pieniążek:

(...) trzeba mieć modum i dzierżeć się go jako pijany płotu, żeby się nie ujmował za rzeczy szkodliwe, za pożyteczne zaś nie brał rzeczy niepożytecznych, pewnych za niepewne. Prawa i wolności nie wyciągá dalej jedno jako rzemień w sobie jest. (E, 181)

Zasadę postępowania, widząc surowość zakonnicy, wskażą Mariannie Marchockiej inni:

„Postępuj tak z sobą, jako $z$ drugimi siostrami”. (Ż, 202)

Śledząc losy autorów, analizując ich świadome wybory i decyzje życiowe, ujawnione w działaniach potrzeby i dążenia możemy stwierdzić, iż reprezentują oni dwie zasadnicze koncepcje życia: vita activa i vita contemplativa.

W filozoficznej literaturze europejskiej oraz polskiej XVI wieku toczyła się dyskusja na temat życia kontemplacyjnego (vita contemplativa) i czynnego (vita activa), której przedmiotem była wartość poznania i działnia w życiu człowieka.

Dominującą orientacją filozoficznej myśli polskiej XVI wieku był praktycyzm. Zakres oddziaływania zwolenników orientacji kontemplacyjncj był o wiele węższy. Przedstawiciele tej orientacji sądzili, iż poznanie doskonali człowieka niezależnie od aktywności praktycznej. Według zwolenników orientacji praktycystycznej - reprezentuje ją w nurcie moralizmu Andrzej Frycz Modrzewski - poznanie posiada wartość wyłącznie w powiązaniu z działaniem, jednostka bowiem realizuje swą doskonałość jedynie poprzez działanie. Mimo istotnej różnicy stanowisk w kwestii wartości poznania, żaden z reprezentantów vitae activae nie twierdził, iż należy działać bez uprzedniej refleksji (teorii) nad tym, jak działać. Nie było również zwolenników vitae contemplativae w czystej postaci. Żaden z typowych przedstawicieli

\footnotetext{
${ }^{5}$ Zob. L. Winniczuk, Humanitas Horacego. (Na marginesie „Satyr”), w tejże: Od starożytności do uspótczesności, Warszawa 1981, s. 142-152.
} 
tej orientacji nie sądził, że należy wyłącznie poznawać, nie realizując w ogóle wartości etycznych lub estetycznych.

Polską literaturę parenetyczną XVI wieku przenika duch rzymskiego praktycyzmu. Poszukuje ona odpowiedzi na pytanie, jak żyć spełniając określone funkcje społeczne w konkretnych warunkach. Zarówno popularne „zwierciadła”, jak i dzieła tej miary co Commentarii de Republica emendanda A. F. Modrzewskiego są wyrazem postawy praktycystycznej6

W nurcie praktycystycznym o zabarwieniu moralistycznym mieści się również Ethica albo Zwierciadto żywota Krzysztofa Pieniążka. Problematyka etyczna, na którą wskazuje pierwszy człon tytułu napisanej w 1607 roku autobiografii, ma istotne znaczenic dla wymowy dzicła. Modelowym wzorcem moralności i życia, do którego odnieść można autobiografię Pieniąż$\mathrm{ka}$, jest koncepcja vitae activae. Etos moralny autora-narratora jest wyrazem świadomości etycznej człowieka renesansu i ma charakter pragmatyczny. W swoim dziele rozważa Pieniążek problematykę normatywną: różnorodne wzorce osobowe, sposoby życia, ale w pewnym stopniu także problematykę egzystencjalną związaną z pytaniem o to, jak kierować własnym życiem, jak osiągnąć „rozkosz”, „pożytek” i jak „ku pewnemu kresowi i uciesznemu przyść”.

Pieniążek sądzi, iż sytuacja człowieka, jego los zależne są od działań innych ludzi, instytucji, szerszych układów i stosunków społecznych. W zasadzie jedynie we wstępie i w zakończeniu utworu pojawia się myśl o zależności losu czlowieka od woli Boga i konieczności podporządkowania się Jego prawom. Przekonanie to jest źródłem ufnej postawy życiowej autora-narratora najsilniej zaznaczającej się w końcowej partii utworu. Człowiek, w rozumieniu autobiografa, w dużym stopniu jest twórcą własnego losu, dysponuje wolnością wyboru sposobu życia. Wewnętrzną zasadą porządkującą życie jednostki powinno być przestrzeganie praw ustanowionych przez przodków i nieustanna refleksja nad własnymi czynami. Natrętne powracanie do kwestii niewłaściwego podziału „dóbr” i „wakancyj” w Rzeczypospolitej świadczyć może o braku poczucia bezpieczeństwa autora. Solidaryzując się z grupą średnio zamożnej szlachty, autor broni zagrożonych a cenionych wartości. Ważne i potrzebne idee społeczne potwierdza własną biografią i refleksją moralną. Wskazuje, jakie są czyny ludzi piastujących wysokic urzędy, a jakie powinny być. Za swą powinność autor uważa przekazanie obrazu „dobrego i porządnego życia”, który zachęci „młódź do usługiwania Ojczyźnic”.

Życiem wartościowym i godnym jest dla większości twórców życic aktywne. Vita activa określa ich ideały życiowe i zasady postępowania. Człowiek — według tej koncepcji życia urodził się po to, aby działał, zdobywał dobra materialne i duchowe, tworzył wiclorakie związki z innymi ludźmi, z ludzką społecznością. Vita activa oznacza życie zaangażowane, twórcze, w którym jest miejsce na służbę, poświęcenie, nawet na heroizm.

\footnotetext{
${ }^{6}$ Zob. J. Czerkawski, Orientacje ideologiczne w Polsce w XVI w. Vita activa, vita contemplativa, [w:] Renesans. Sztuka i ideologia, Warszawa 1976, s. 43-44.
} 
Potrzebę nieustannej ludzkiej aktywności szczególnie mocno akcentują autobiografie z czasów panowania Zygmunta Augusta, Stefana Batorego, Zygmunta III. Za osłabienie własnej aktywności, ustanie w pracy surowo oceniony zostanie król Stefan Batory:

Szkoda, królu, że i owe lat kilka, po wielkich pracach, do których byłeś za młodu przyuczon, odpoczywając zabawiałeś w Grodnie! Mojem zdaniem, gdybyś zwykłej oddawał się pracy, jeszcze być dłużej był potrwał! ${ }^{7}$

Człowiek realizujący ideał życia kontemplacyjnego nastawiony jest na zaspokojenie potrzeb i dążeń innej natury; dominuje u niego potrzeba doskonalenia wewnętrznego. Może to prowadzić do przyjęcia postawy, jaką reprezentują karmelitanki. Zapatrzone w ideał życia zakonnego nie wierzą, że uczestnicząc w życiu społeczeństwa potrafią dotrzymać wierności własnym ideałom i cenionym wartościom. Jadwiga Stobieńska, Marianna Marchocka decydują się — wbrew opiniom środowiska - na życie w zgromadzeniu karmelitanek w nadziei na zachowanie pewnych wartości i rozwijanie własnej odrębności. Wybrały drogę doskonalenia wewnętrznego.

Opisy doznań psychicznych, miłości do Boga, sposobu rozumienia Go i przeżywania w autobiografiach mistycznych mają często charakter pogłębionych, precyzyjnych analiz, świadczą o znacznej kulturze wewnętrznej karmelitanek, bogactwie ich życia duchowego i niemałej sprawności językowej. Autorki potrafią dokładnie wyrazić w słowach to, o czym myślą, co czują. Bóg w ich świecie był wartością najwyższą, ale wartością ludzką. Droga do Niego prowadzi poprzez człowieka: przez poznanie siebie, zrozumienie innego człowieka. Vita contemplativa wymaga obecności i pomocy drugiego człowieka. O szerszych związkach ze światem człowieka realizującego ten ideał życia świadczą chociażby kontakty Marchockiej z królową Ludwiką Marią, królem Janem Kazimicrzem i kanclerzem Jerzym Ossolińskim.

Koncepcja życia aktywnego i model życia kontemplacyjnego realizowane są w sposób świadomy, ale także w sposób nieuświadomiony. Różnią się one dominantą określonych potrzeb, przewagę uzyskuje któryś z wymiarów życia.

Autobiografie, których twórcy w sposób mniej lub bardziej uświadomiony realizują aktywną koncepcję życia, ukazują człowieka w społecznym, gospodarczym i kulturalnym wymiarze życia.

Wymiar psychiczny i kulturalny dominuje w autobiografii Anny Stanisławskiej, a przede wszystkim w autobiografiach mistycznych.

Dwa sposoby życia: życie kontemplacyjne i życie czynne oddziaływują na siebie, w każdym jest coś z drugiego. Wyróżniając je pragnie się zaznaczyć, iż u jednej kategorii ludzi przeważa pierwiastek kontemplacyjny, czyli szukanie prawdy, inni natomiast oddają się czynnościom, co nie wyklucza całkowicie pierwiastka kontemplacyjnego w ich życiu. Jedni

\footnotetext{
7 T. Jewłaszewski. Pamiętnik... nou'ogrodzkiego podsędka. 1546-1604. Przeklad z języka zachodnioruskiego, wyd.
} T. L[ubomirski], Warszawa 1860, s. 51-52. 
są skierowani ku prawdzie, drudzy są nastawieni na czyn, działanie zewnętrzne, a więc na życie praktyczne.

Vita activa i vita contemplativa - te dwie koncepcje życia i powołania człowieka przenikają się wzajemnie i najczęściej różnice między nimi mają charakter różnicy głównego akcentu.

W wersji udoskonalonej koncepcja życia aktywnego nie musi być przeciwstawiona koncepcji życia kontemplacyjnego. Życie aktywne może zawierać w sobie element dążenia do wartości duchowych, wyższych; może uzyskać oparcie w filozofii, etyce, religii.

Zaprezentowane tu dwa modele ludzkiej egzystencji można nazwać także horyzontalną i wertykalną koncepcją życia. Nazw tych użyto jednak w nieco innym znaczeniu, niż uczynił to B. Suchodolski, charakteryzując obie koncepcje ${ }^{8}$. Wertykalizm dążeń ludzkich nie oznacza egoistycznej potrzeby wyróżnicnia się, pięcia w górę, osiągnięcia awansu spolecznego i ekonomicznego. Przypisuję mu takie znaczenic, w jakim użył go J. S. Pasierb, pisząc o doniosłości pionowego wymiaru kultury ${ }^{9}$. Wertykalna koncepcja życia oznacza otwarcie człowieka na wartości transcendentne, humanizm dążący do Boga. Byłaby to koncepcja egzystencji człowieka-twórcy, który nadaje życiu zgodny ze swoją wolą kształt i kierunek. Źródła filozofii takiego człowieka tkwią $w$ religii. W religii znajduje on odpowiedź na zasadnicze pytania dotyczące jego życia i w jej perspektywie przeprowadza hierarchizację wartości, wyodrębnia wartości naczelne.

Autobiografie Jana Rybińskiego ${ }^{10}$, Teodora Jewłaszewskiego, a przede wszystkim autobiografie poetów: Klemensa Janicjusza ${ }^{11}$ i Jana Dantyszka ${ }^{12}$ dowodzą, iz poszukiwania wartości transcendentnych nie jest pozbawiona egzystencja człowieka realizującego w zasadzie koncepcję życia aktywnego. Dlatego można powiedzieć, iż większość twórców wydaje się bliska ideałowi trzeciemu: vita mixta. Ten typ życia przebiega jakby równocześnie w dwóch wymiarach: w wymiarze poglębionej refleksji filozoficznej, religijnej czy wewnątrzzakonnej kontemplacji oraz w wymiarze społecznym jako zaangażowany dialog z duchem własnych czasów. Oznacza to w praktyce, iz indywidualność i postępowanie autorów kształtowała z jednej strony wiara, religia, a z drugiej — patriotyzm. Mimo pełnej świadomości odrębności własnego życia i osoby, twórcy staropolscy nie oddzielali siebie od losów rodziny, rodu, społeczeństwa.

\footnotetext{
${ }^{8}$ Zob. Strategia życia. Rozważania i dyskusje na sympozjum w Jabtonnie. Materialy, red. B. Suchodolski, Wrocław 1983, s. 72, 116-120.

${ }_{9}$ Zob. J. S. Pasierb, Pionowy wymiar kultury, Kraków 1983.

${ }^{10}$ Autobiografia Jana Rybiniskiego, seniora Braci Czeskich, wyd. A. Danysz, „Reformacja w Polsce” nr 8, Warszawa 1922, s. 305-314.

$"$ Zob. K. Janicki, Carmina. Dzieła wszystkie, opr. J. Krókowski, J. Mosdorf, przeł. E. Jędrkiewicz, Wrocław 1966, s. 48-59 i 351-353 (komentarz): De se ipso ad posteritatem, cum in summo vitae discrimine versaretur, quod tamen evaserat - O sobie samym do potomności pisze podczas bardzo ciężkiej choroby, zktórej jednak wyszedt (Tristia VII).

12 Zob.J. Dantyszek, Carmina, wyd. S. Skimina, Kraków 1950, s. 295-301:Vita Ioannis Dantisci (Carmina XLIX).
} 


\section{2.}

Autobiografię traktuję jako jeden z gatunków piśmiennictwa staropolskiego, wytwór czynności twórczych. Akt wspominania jest, w moim przekonaniu, czynnością twórczą, prowadzi do poznania $^{13}$.

W polskim tłumaczeniu Tablic definicji G. W. Leibniza wśród wyrazów nazywających odczucia wewnętrzne zaraz po wyrazie „poznanie” objaśnia się rzeczownik „pamięć”. „Pamięć jest to powtórne poznanie wywodzące się z wcześniejszego" ${ }^{14}$.

Twórca przypomina wydarzenia swojego życia, bo jest przekonany o ich doniosłości w perspektywie osobistej i społecznej, narodowej. Autorzy staropolskich autobiografii byli głęboko zaangażowani w rzeczywistość społeczną, polityczną, w „świat zawikłany” swojej epoki. Własne życie ujmowali często jako „służbę w Rzeczypospolitej”. Przypominali znaczące sytuacje i zdarzenia, aby je przybliżyć odbiorcy i uprzystępnić, ale także dlatego, by je ocenić przed sobą i dla siebie, przed czytelnikiem i dla niego:

Jak się zaś wojna szwedzka skończyła, wie o tym cała Ojczyzna i kronikarze szerzej o tym napiszą. Ja tylko to piszę, na której wojnie byłem i czegom się z młodu uczył aż do starości.

(...) u nas czasem więcej bywa regimentarzów w wojsku aniżeli pułków i dlatego ludzie giną.

(...) jak wiele wojska zginęło i prawie wszyscy porucznicy, wiadomo całemu światu polskiemu było, jak się z tym nie szyrzę ${ }^{15}$.

Psychologiczną i historyczną swoistość autobiografii staropolskich określa ich zależność od funkcjonujących społecznie wzorców osobowych, ideałów. Autobiograf nie tylko sytuuje siebie wobec ideałów i wzorców odpowiadających jego stanowi, profesji, pozycji społecznej, ale wręcz utożsamia się z nimi, zmierza w toku relacji o tym, czym i w jaki sposób wypełnił swe życie, do uświadomienia odbiorcy, iż służył ideałom, a życie jego było wartościowe i godne. Postawa taka pozostaje w ścisłym związku z zamierzonym dydaktyzmem przekazu autobiograficznego.

Można mówić o pewnej wspólnej postawie autobiografów wobec świata, polegającej między innymi na przeciwstawieniu siebie innym. Bohaterowie Jerzego Ossolińskiego ${ }^{16}$

\footnotetext{
${ }^{13}$ O wyznacznikach gatunkowych i najistotniejszych kontekstach interpretacyjnych autobiografii staropolskich szerzej w: H. Popławska, U początków autobiografii staropolskiej. Kryteria i konteksty, „Gdańskie Zeszyty Humanistyczne" nr 30, Gdańsk 1987, s. 107-126.

${ }^{14}$ G. W. Leibniz, Tabulae definitionum, przeł. A. Kamieńska, W. Werpachowska, [w:] Stownik i semantyka. Definicje semantyczne, praca zbiorowa pod red. H. Janus, Wrocław-Warszawa 1975, s. 60.

15 J. F. Drobysz Tuszyński, Pamiętnik..., [w:] Dwa pamiętniki z XVII wieku, Jana Cedrowskiego i Jana Floriana Drobysza Tuszyńskiego, wyd. i wst. A. Przyboś, Wrocław-Kraków 1954, s. 31-32, 53.

${ }^{16} \mathrm{~J}$. Ossoliński, Pamiętnik, oprac. i wst. W. Czapliński, Warszawa 1976.
} 
zgodnie z konwencją epopeiczną są zhiperbolizowani. Idealizacji podlega postać narratora-bohatera, natomiast postać Stanisława Kazanowskiego ${ }^{17}$ jest wyraźnie zdemonizowana: autor wyznaczył tej postaci rolę swego przeciwnika. Rolę taką istotnic przez całe życie kanclerza Ossolińskiego pełnił Stanisław Kazanowski. Idealizująca i heroizująca stylizacja na obrońcę ojczyzny — pojawia się również w konstrukcji postaci mężów w Transakcyi Anny Stanisławskiej oraz w autobiografii Jana Sobieskiego ${ }^{18}$. W autobiografiach Ossolińskiego, Stanisławskiej, Sobieskiego widoczne są związki „wysokości” etycznej z „wysokością” stanową bohaterów i tragiczną tonacją utworu.

Uderza, jak wiele jest w autobiografiach ujęć podobnych, trwałych tematów. Dzieciństwo traktowane jest najczęściej jako okres, w którym ujawniają się zamiłowania, późniejszy talent, kształtuje powołanie człowieka. Młodość przez mężczyzn bywa najczęściej ujmowana jako czas „durny”, okres szczególnie niebezpieczny dla rozwoju moralnego, wymagający właściwego ukierunkowania i opieki ze strony osób dojrzałych. O młodości Jan Stanisław Jabłonowski napisał, iz nie był wówczas „swoim panem” "19 Młodość rozumiana jest również jako okres sprawdzania fizycznej sprawności człowieka, wyrabiania charakteru i dzielności moralnej (Jerzy Ossoliński). Autobiografie szesnasto- i siedemnastowieczne ujawniają przystosowanie tradycyjnych wzorów osobowych greckich i rzymskich do sytuacji staropolskiej. Polonizacja konwencjonalnych ujęć w konstrukcji postaci i w warstwie językowo-stylistycznej najwyraźniej ujawnia się chyba w autobiografiach Pieniążka, Ossolińskiego, Sobieskiego.

W autobiografii staropolskiej chodzi o ujawnienie psychologicznej (anima) i moralnej (ethica, humanitas) struktury postaci bohatera określonej przez wzorce osobowe. Istotną właściwością tych tekstów jest brak informacji o wyglądzie autora-bohatera. Nastawione są one przede wszystkim na ewokowanie moralnej struktury postaci przedstawionych. Być może, takie ujęcie własnej osoby jest nie tylko wynikiem konwencji retorycznej ${ }^{20}$, ale przejawem jakiejś trwałej potrzeby człowieka skłaniającej go do dania wyrazu temu, co określa go w większym stopniu niż wygląd zewnętrzny.

Adresat utworu dysponuje zwykle możliwością sprawdzenia prawdziwości, zgodności z rzeczywistością autorskich przedstawień, ocen i postaw. Pragnienie wpłynięcia na osobo-

17 Stanisław Kazanowski, starosta krośnieński, jaworowski, przedborski; najbliższy dworzanin i rówieśnik królewicza Władysława, którego wychowawcą był jego ojciec, Zygmunt (podkomorzy wielki koronny, starosta kokenhauski). W autobiografii Jerzy Ossoliński wspomina, jak w czasie kampanii moskiewskiej (1617 r.) za przyczyną Stanisława Kazanowskiego doznał w obozie wojskowym wielu krzywd. Przez cale życie pozostał Ossoliński w głębokim konflikcie ze Stanisławem Kazanowskim i jego bratem, Adamem. (O Stanisławie Kazanowskim i intrygach w obozie wojskowym w czasie wyprawy moskiewskiej zob.: W. Czapliński, Wladystaw IV i jego czasy, Warszawa 1976, s. 41-43, 60).

${ }_{18}$ Ekscerpt z manuskryptu wlasnej ręki Najjaśniejszego Króla Je. Mci s. p. Jana Trzeciego, [w:] Pisma do wieku i spraw Jana Sobieskiego, wyd. F. Kluczyński, t. 1, cz. 1, Kraków 1880, s. 1-9 (Acta Historica res gestas Poloniae illustrantia, vol. II).

${ }_{19}$ Pamiętnik Jana Stanistawa Jabtonowskiego wojewody ruskiego, wyd. A. Bielowski, Lwów 1862, s. 42.

${ }^{20}$ Zob. T. Michałowska, Między poezją a uymowq. Konwencje i tradycje staropolskiej prozy nowelistycznej, Wroclaw-Warszawa 1970, s. 124, 140, 145, 293, 301. 
wość odbiorcy, kształtowania jego postawy moralnej stanowi dla twórcy staropolskiego czynik uzasadniający podjęcie wypowiedzi o charakterze autobiograficznym. O rozpoczęciu dialogu z odbiorcą decyduje swoiste poczucie obowiązku wobec przeszłości i przyszłości. Autobiograf osadzony w teraźniejszości, rekonstruujący i interpretujący swą przeszłość, sięgający po nią ze swojego dziś, nie zna przyszłości, ale w przyszłość wychyla się swą wypowiedzią skierowaną do syna, bliskich, czytelnika. Nadawca i odbiorca sytuują się w jednym czasie bądź nadawca zwraca się do odbiorcy usytuowanego w przyszłości; pośredniczy między nimi tradycja rodowa i narodowa. Autobiografia staje się ekspresją wewnętrznej prawdy człowieka, wynikającej z konkretnej sytuacji, w jakiej człowiek ów się znalazł. Odbiorca chcąc zrozumieć całość zachowania autora musi zdać sobie sprawę z podstawowych wartości motywujących to zachowanie, musi poznać i uwzględnić różnorakie motywacje: psychologiczne, społeczne, religijne, odczytać ostateczny cel ludzkiej egzystencji. „Chowałem się do akademii niebieskiej” - powie o sobie Jan Rybiński i będzie to ostatnie zdanie jego autobiografii ${ }^{21}$.

Analiza autobiografii staropolskich wykazuje, iz w zasadzie brak w nich refleksji nad śmiercią, problematyki końca własnej egzystencji. Wyjątek stanowią autobiografie poetyckie: Klemensa Janicjusza, Jana Dantyszka, Macieja Stryjkowskiego ${ }^{22}$ i Anny Stanisławskiej. Refleksje na temat śmierci pojawiają się również w autobiografii mistycznej Marianny Marchockiej. Można chyba uznać, iż bliscy tej problematyki są ci autorzy, którzy w zakończeniu swoich utworów podają często obszerne wykazy zmarłych w ostatnich czasach krewnych, przyjaciół, znajomych.

Autobiografie pisarzy wykorzystują napięcie między przeszłością a przyszłością. Sytuacja podmiotu w Tristia VII (ze zbioru Tristium liber) Klemensa Janicjusza jest dramatyczna, określić można ją jako sytuację utraty przyszłości. Poeta, świadomy rychłego kresu swego życia, ma poczucie, iż nie udało mu się w pełni zrealizować zamierzeń twórczych. Punktem wyjścia elegii Janicjusza - autobiografii Stryjkowskiego także - jest przekonanie, iz przyszłe pokolenia czytelników będą zainteresowane dziejami życia pisarza. Dorobek twórczy pisarza zapewnia mu trwanie w świadomości potomnych. W ten sposób zarysowuje się przed poetą przyszłość, a fakt utraty życia staje się mniej groźny, bo jakby nie ostateczny; siła niszcząca śmierci ulega ograniczeniu i osłabieniu. Ponadto artyści nie przypisują śmierci charakteru absolutnego, przyjmują jakiś rodzaj egzystencji po śmierci. Optymistyczną, mimo wszystko, pełną ufności postawę pisarzy wzmacnia wiara w czekające ich po śmierci życie wieczne. Dzieje artysty, historia jego twórczości przedstawione są i pojmowane niemal wyłącznie jako dzieje człowieka złączonego wiarą z Bogiem. Wszystie wydarzenia życia pisarza pozostają otwarte na Boga, są objęte Jego działaniem i podlegają Jego kierownictwu.

\footnotetext{
${ }^{21}$ Autobiografia Jana Rybińskiego..., op. cit., s. 314.

${ }^{22}$ M. Stryjkowski, Sam o sobie i przygodach swoich w zwiedzaniu rozmaitych krain świata, [w tegoż:] Która przedtem nigdy światta nie widziala, Kronika polska, litewska, żmodzka i wszystkiej Rusi, wyd. M. Malinowski, t. 1, Warszawa 1846.
} 
Pozytywny sąd poetów: Klemensa Janicjusza i Jana Dantyszka o śmierci ma swoje źródła w postawie właściwej chrześcijaństwu. Chrześcijaństwo dramatyzuje pragnienie śmierci, które staje się pragnieniem samego Boga, pełni zbawienia. Świadomość, iż człowiek nie rozporządza sam swoim życiem, prowadzi chrześcijanina do postawy ufności, miłości. Człowiek jest istotą przemijającą i nie ma trwałości sam w sobie ${ }^{23}$.

Janicjusz na własnym przykladzie ukazuje, jak człowiek pragnie osiągnąć życie sam z siebie lub przy pomocy innych ludzi, a ostatecznie może je uzyskać jedynie od Chrystusa. Podobnie Dantyszek odwołuje się do chrystologicznej wizji człowieka; jego Vita Ioannis Dantisci jest historią drogi człowieka wierzącego, chrześcijanina, którego ostatecznym powołaniem jest szczęście zbawienia.

Zagadnienie stosunku autorów do mijającego czasu, do śmierci na pewno wymaga głębszej analizy. W tym miejscu należy mocno podkreślić jedną z ważnych funkcji autobiografii, a mianowicie jej funkcję katartyczną.

Arystoteles wiązał katharsis wyłącznie $z$ działaniem tragedii. Natomiast w okresie renesansu wskazywano, że poezja heroiczna działa podobnie jak tragedia; działanie oczyszczające, uwalniające od uczuć negatywnych przypisywano ponadto noweli. Michel Angelo Buonarotti w wykładzie o Petrarce wygłoszonym w Akademii della Crusca wspomniał o katharsis mówiąc o odbiorze sztuk piçknych. Renesansowi teoretycy chętnie akcentowali medyczny wymiar katharsis i ukazywali jej potrzebę w kategoriach moralno-leczniczych. Celem tak pojętej katharis było uniewżanienie rzeczywistości, uwolnienie się od niej ${ }^{24}$.

Autobiografowie staropolscy mieli świadomość katartycznej funkcji swej wypowiedzi. Poglądy w tej sprawie często wyrażali wprost. Pragnęli uwolnić siebie i odbiorcę od napięć uczuciowych wywołanych przez trudne sytuacje, które niesie ze sobą rzeczywistość. Pragnienie takie wyraził Krzysztof Pieniążek, który przypisał swojemu utworowi także moc pocieszenia. Anna Stanisławska przekonana była, iż tylko spisanie własnych dziejów uwolnić ją może od ciężaru przykrych przeżyć. Wielkie nadzieje wiązała ze swoimi wyznaniami Marianna Marchocka. Wielokrotnie w toku swoich rozważań dawała wyraz pragnieniu mówienia, podzielenia się z kimś bliskim i rozumiejącym własnymi przeżyciami. Autorka poszukiwała rady, pomocy i wsparcia drugiego człowieka; milczenic było dla niej ciężarem i cierpieniem:

Bo wszystko pragnienie moje w tym pisaniu jest wylać jako przed Bogiem, jak najjaśniej duszę moję, a tak dopiero pokój i kontentacja ostatka żywota mego będzie. O jeśli to podobna, żeby taki sposób osobliwy łaski i dobroci Boski miał mi być na takie krzyże i cierpienie moje?

(Z, 177-178)

${ }_{23}$ Zob. J. Ratzinger, Śmieŕ́ i życie wieczne, przeł. M. Węcławski, Warszawa 1986, s. 110.

${ }^{24}$ Zob. A. Kuczyńska, Czlowiek i śutiat. Wątki antropologiczne w' poetykach renesansu ułoskiego, Warszawa 1976,

s. 142-157. 
Podjęcie relacji autobiograficznej było zwrotem twórców ku drugiemu człowiekowi, ku życiu i czasowi, który minąt, ale nie jest znakiem śmierci. Świat ludzki i życie ludzkie ma w ich utworach swoje wymiary czasowe i nie oznacza tylko przeszłości czy tylko teraźniejszości. W sposobie rozumienia czasu, który nie był dla twórców jedynie mocą niszczącą, autobiografowie staropolscy bliscy byli filozoficznej myśli Seneki, jak również koncepcji renesansowego filozofa i uczonego Girolamo Cardano mówiącego: „Czas to moje pole”25. Nawet w późnych, schyłkowych latach swego żywota, często po trudnych, bolesnych doświadczeniach autobiografowie staropolscy stawali po optymistycznej stronie życia.

${ }^{2}$ Cyt. za J. Ochman, Wstęp do: G. Cardano, Autobiografia, Wrocław 1974, s. XXX. 